Reference: Rogers, C. (2016) 'I'm complicit and I'm ambivalent and that's crazy': care-less spaces for women in the academy' Women's Studies International Forum http://dx.doi.org/10.1016/j.wsif.2016.07.002

\begin{abstract}
This paper is about three working class women academics in their 40s, who are at different phases in their career. I take a reflexive, feminist, (Reay 2000, 2004, Ribbens and Edwards 1998) life story approach (Plummer, 2001) in order to understand their particular narratives about identity, complicity, relationships and discomfort within the academy, and then how they inhabit care-less spaces. However unique their narratives, I am able to explore an aspect of higher education - women and their working relationships - through a lens of care-less spaces, and argue that care-less-ness in the academy, can create and reproduce animosity and collusion. Notably, this is damaging for intellectual pursuits, knowledge production and markedly, the identity of woman academics. In introducing this work, I first contextualise women in the academy and define the term care-less spaces, then move onto discuss feminist methods. I then explore and critique in some detail, the substantive findings under the headings of 'complicity and 'faking' it' and 'publishing and collaboration'. The final section concludes the paper by drawing on Herring's (2013) legal premise, in the context of care ethics, as a way to interrogate particular care-less spaces within higher education.
\end{abstract}

\title{
"I'm complicit and I'm ambivalent and that's crazy": care-less spaces for women in the academy
}

\section{Introduction}

This paper is about three working class women academics in their 40s, who are at different phases in their career. I take a reflexive, feminist, (Reay 2000, 2004, Ribbens and Edwards 1998) life story approach (Plummer, 2001) in order to understand their particular narratives about identity, complicity, relationships and discomfort within the academy, and then how they inhabit care-less spaces. However unique their narratives, I am able to explore an aspect of higher education - women and their working relationships - through a lens of care-less spaces, and argue that care-less-ness in the academy, can create and reproduce animosity and collusion. Notably, I want to argue that this is damaging for intellectual pursuits, knowledge production and markedly, the identity of woman academics. In introducing this work, I first contextualise women in the academy and define the term care-less spaces then move onto discuss feminist methods. I then explore and critique in some detail, the substantive findings under the headings of 'complicity and 'faking' it' and 'publishing and collaboration'. The final section concludes the paper by drawing on Herring's (2013) legal premise, in the context of care ethics, as a way to interrogate particular care-less spaces within higher education.

\section{Contextualising the subject: silencing women}

The intersections between gender, class, race, and so on are evident within the academy, but for this paper I intend to focus closely on gender, and particularly working class women. As it is women, in comparison to men, who populate lower grades in higher education, are less likely 
to be a principal investigator (PI) in research, and their promotion has not kept a pace with the recruitment of women students (Aiston, 2014; Hoskins, 2010; Morley, 2014). Moreover, silences about women 'pulling up the ladder' behind them, lacking care and 'feminist elbows' arguably needs discussing, (Skelton, 2005: 327-328). Furthermore, the guilt, particularly working class women feel, if they complain too much, can be silencing, if not paralysing (Gill, 2010; Gill and Donaghue, 2016). Yet, there are too many women who are silenced, and silencing is a tool of oppression. For 'when you are silenced, whether by explicit force or by persuasion, it is not simply that you do not speak, but that you are barred from participation in a conversation which nevertheless involves you' (Ahmed, 2010: xvi). Not only are there silencing practices that permeate academia, 'toxic shame' is apparent, where one might embody a sense of illegitimacy in the work place due to cruel reviews of work, promotion failure, lack of funding and classed identity (Gill, 2010: 238; see also Back, 2016). Also, if women cannot trust powerful others to perform and embody care, generosity and respect, can they ever really speak out about their position, feelings and identity construction?

Care-less-ness within institutions; in this case the university, and a 'lack of trust can be a reason not to speak' (Ahmed, 2010: xvi). Thus, as Sumi Madhok and her colleagues suggest in discussing gender, coercion and agency,

We live our lives in a period marked by economic, political, and cultural inequalities; are ever more intimately touched by these; and are implicated, willingly or not, in a range of coercive practices. Yet at this very moment, we are told that we enjoy unprecedented levels of freedom, are offered a disorientating array of choices and assured protection by a list of individual rights that is longer than ever before (Madhok, Phillips and Wilson, 2013: 5).

Critically, the legitimacy of bemoaning the position women academics inhabit, can seem questionable due to the 'privilege' that comes with it (Madhok et al. 2013, Hoskins, 2010). However, I want to argue that women academics in particular, are often complicit within their working life, colluding with those in more 'powerful' positions, and on occasion 'fake' good relationships with colleagues, managers, research partners and students, so as to project a legitimate and valid academic identity. Moreover, even if there is recognition that there are institutional and relationship problems that result in dangerous practices for staff, a flood of sessions on wellbeing, mindfulness, equality, time-management and leadership, are offered to help (Gill and Donaghue, 2015), implying care-full practices are adhered to.

\section{Care-less spaces in the academy}

I have spent some time thinking about care-less spaces in the context of intellectual disability and feminist ethics of care. Indeed, my latest work (author b) develops a care ethics model of disability where I found many care-less spaces, in schools, the home, local authorities, friendships (intimate or not), communities, the health service and so on. Care-less spaces are also found in a number of other areas such as the criminal justice system, commercial and private businesses and not least of all universities. My argument here is that my care ethics model can map onto higher education, because the premise of the model is not about disability per se, but fundamentally about social and political relations where care-less-ness is abuse emotionally, practically and socio-politically. As it stands my care ethics model proposes three spheres of caring work, but these are currently populated with care-less spaces. The caring spheres are: The Emotional Caring Sphere - where love and care are psycho-socially questioned; The Practical Caring Sphere - where day to day care is carried out relationally and 
The Socio-political Caring Sphere - where social intolerance and aversion to difficult differences are played out. These three spheres all interact in complex ways and are grounded in social and political relations that seek caring legal and cultural processes.

Grounding care-less spaces within a care ethics model, I turn to early key thinkers in feminist ethics of care, including Nel Noddings (2003), Sara Ruddick (1989) and Joan Tronto (1993). These feminists composed accounts of the particular relationship between women and ethics of care. This often involved a consideration of the mother-child relationship as a specific and significant example of the intertwining of ethics and everyday life. Whilst the embodied aspects of motherhood are fully recognised, it is the gendering of the social roles of women, and indeed of morality, which are emphasised, producing accounts of moral reasoning which are grounded in, but not limited to, women's experiences of care. For my study here, this translates into women and their role within the academy, as I focus on aspects of the everyday relational life of women academics. From this perspective, care is understood and presented as a practice and as a way of thinking. Yet, often, within these areas of 'caring' I discover care-less spaces that damage, thwart, and contest caring work. Indeed, within these spaces women are in danger because they are inhabiting the care-less space that is all encompassing as it permeates the emotional, practical and socio-political spheres every day.

The development of a feminist ethics of care sought to define care in more grounded terms, but also, at a philosophical level, it has aimed to reposition and argue for the value of care as a basis for moral and political theory as well as for social policy. Importantly too, in thinking beyond the emotional and practical spheres and into the socio-political sphere where we recognise social justice and care, mass systemic violence is recognised. Significantly, in mapping care-less spaces Noddings's (2003) work is important in the conceptualisation of care and caring as an alternative moral theory, and offers a detailed definition of care as a central, crucial and human practice. She presents, as do others (for example, Ruddick, 1989), care as a practice and therefore as learnt and, importantly, as improvable, but also argues that experiences of being cared for are definitively human, or 'universally accessible' (Noddings, 2003: 5). This point illustrates a significant theme in feminist ethics, which is to highlight the commonality of human vulnerability, not just at the beginning and end of life, but as a constant and fundamental condition.

Broadly, I suggest that care and caring are not necessarily about individual rights and freedom per se, as this detracts from the politics of care and assumes a paternalistic state of doing and being. In the framing of this paper, because an 'ethics of care that is political and critical must be grounded in the concrete activities of real people in the context of social relations' (Mahon and Robinson, 2011: 2), I seek to explore the concrete activities and social relations of three women academics as a way to understand the experiences of inhabiting care-less spaces. This is because all of these areas, once introduced within academic life, are influenced by the macro and micro politics of higher education. Moreover, it has not gone unnoticed that higher education, is arguably increasingly restrictive, bounded and less creative (Back 2016, Evans 2004). Yet, 'creativity, motivation and resistance are all necessary for intellectual endeavour' (Mauthner and Bell, 2007: 96).

Discussing care-less-ness in academia therefore is palpable, due to the enormity of gendered caring activity, both formal and informal, and the continued inequality within the academy for women (Evans, 2011; Lynch, 2010; Morley, 2014). This is largely as a result of the expectation of women to adhere to, and perform caring and care-full practices. By highlighting care-less 
spaces, via three women's narratives, I explore mistrust, complicity and discomfort within particular academic roles and relationships. Crucially I question if these spaces and relationships are sustainable, safe, care-full and just. Because as Jonathan Herring (2013: 45) suggests, care 'is not a strange activity which is undertaken by a few brave souls, but it is ingrained into the existence of every person'.

It is evident that philosophically, moral reasoning based on justice which 'asserts that morality is about the objective application of univesalizable principles among mutually disinterested, disembodied individuals' (Robinson, 2011: 5) is wholly inappropriate in the academy and social life more broadly. As none of us live in a world of abstraction; we live in a world of relationships, in the real world. Therefore, in developing feminist ethics and within my care ethics model, human safety, trust, responsibility, respect and care-full practices and relationships are key. Furthermore, there is and ought to be an alternative to Kantian rights based ethics (Author, b). Fiona Robinson (2011) in her work looks at human security (or safety) via a feminist ethics of care, and in my analysis, I begin to see how the emotional, practical and socio-political spheres leak into and out of private and public life for women academics, particularly working class women. Furthermore, women have been considered less than able and irrational, and certainly populate fewer authoritative and leadership positions (Aiston, 2014; Madhok et al. 2013; Morley, 2014). They are therefore in danger of abuse - emotional or otherwise, and are largely unsafe.

People are interdependent and economies are reliant on caring practices, and that includes how higher education produces knowledge and nurtures women academics. I agree with Robinson, in her approach to an ethics of care as she makes an ontological shift; 'one that allows us to see moral subjects as relational and to recognize ethics as fulfilling responsibilities through practices of care' (2011: 28). I understand that life in the academy can be messy, exhausting and at times unbearable and cause human suffering (Gill and Donaghue 2016, Hoskins 2010, Ryan-Flood and Gill 2010). In addition, autonomous human beings are only that; autonomous, if they are in safe and care-full relations. Yet, to only view these relations via social justice based arguments, or other rights framed positions (e.g. Nussbaum, 2011), rather than through interdependency, feminist care ethics and caring practices there is a danger of paternalisation where so called autonomous and powerful others 'care for' those who are in a subordinate position. This is dangerous, as experiencing care-less-ness, emotionally, practically and sociopolitically, is 'a serious human deprivation for most people' (Lynch et al. 2009: 1). Indeed, Robinson (2011: 14) goes as far as to say we need to foreground and prioritise a politics of care ethics so as to 'recover human security' because being without care, human safety suffers. Moreover, the academy is full of cultural and social norms, but they are not in and of themselves anything without interdependent relationships.

The academy is populated with friends, colleagues, professionals, mentors and so on. My argument is that:

1. politically, a feminist ethics of care 'seeks solutions to the problems of the giving and receiving of care that are nonexploitative, equitable, and adequate to ensure the flourishing of all persons' (Robinson, 2011: 33), and

2. caring and responsibility, in addition to a sense of security for women academics (in particular), are challenging to achieve in this current climate.

It is through particular and gendered webs of relationships, that focus on freedom from fear and positive care-full relational action rather than human rights or absolute social justice based 
tactics that prove hopeful and beneficial for women academics. As women academics ought to feel safe, secure and free from fear. After all, 'rights alone may not be able to do the "moral work" that it needs to in order to provide a complete ethics' (ibid 49).

\section{Discussing methods}

\section{Introduction: doing feminist qualitative research}

A qualitative approach offers a snapshot in time; it is historically grounded and the views expressed are often fluid and subject to change as the respondents construct and reconstruct their experiences sometimes in the process of being interviewed. Thus, the data presented in this paper is partial and incomplete; an insight into a story in progress rather than a final or conclusive account (Hoskins, 2010: 136).

Kate Hoskins in this quote, captures the position of feminist qualitative research as I do here. That all knowledge is partial and always in and of the moment. An interviewee's story is presented and re-presented in a particular way and at a particular point in time. Furthermore, it is not unusual to elicit and explore aspects of social life via small numbers of participants so as to explore empirical or theoretical points. For example, Lewis (2010) and Reay (2002) both utilise one life story interview to write about emotional encounters and masculinity, respectfully, and Hoskins (2010) draws upon three white working class women academics in order to explore success within the academy. I too, with Helen Lucey, have previously written about three women's accounts of past relationships with their PhD supervisors (Author $\mathrm{g}$ ). These women were accessed in the same way I accessed my participants for this paper, that is, via personal networks. But as we stated then, all three stories were 'necessarily one-sided accounts', (Author g: 22) because any third parties discussed were always from the perspective of the participant only. For this paper, it is no different.

\section{Motivation for the paper: reflexivity and process}

The motivation behind this paper about women and care-less spaces in the academy was twofold. First, as discussed above, my time spent working on a care ethics model of disability led me to recognise the reach of understanding care-less-ness socio-politically. Secondly, as a member of 'Women's Workshop' we began to discuss our own personal experiences of working within the academy. It was then I realised my care ethics model was alive in the careless spaces narrated. As it is, the 'Woman's Workshop', a supportive, care-full, woman only group, has published a number of books and articles. I joined the group as a $\mathrm{PhD}$ student in 2001, an active member, but not as a contributor to the project that was currently underway. Melanie, Maxine, Julie and Tina were editing Ethics in qualitative research, (Mauthner et al, 2002). It was after that publication I became fully involved in the collaborative writing process. Always supportive, but not without heated disagreements at times. My experience, in the main, has been that it is an honest and trusting, indeed a care-full space.

As a full participator in the book Val and Helen edited, Power, Knowledge and the Academy, (Gillies and Lucey, 2007), I had the pleasure of working with Helen Lucey (author g). She was one of the most caring and encouraging women academics I have worked with. It was after that book and further meetings, the next book evolved. Susie and I edited a book premised on care, called Critical Approaches to Care (Author h). This was largely because all the preamble discussions kept coming back to the fact that,

members often research areas of great personal interest and, therefore, there is a sense in which they care deeply about their subject and participants. Care is apparent in the 
ethos of the group; members care for and about the group and its members, often sharing in both personal and professional elations and sadness (author i, 2013: 10 [emphasis in original]).

It was no surprise then, as we began the next journey into future publications that issues discussed around the table were about higher education: the highs and lows, research assessment, competition, collegiality, complicity and collusion included. I too had experienced my own complicity, collusion, competition and collegiality and wanted to research further about this aspect of university life via other women academic's stories. In our workshop group discussions, it was clear many of my colleagues were inhabiting or had experienced care-less spaces in their academic careers.

\section{Three women: Donna, Megan and Wendi}

In 2015 I interviewed three white British working class women academics who were in their forties. I recognise the intersections between class and gender and how this impacts women in higher education, yet I do not have the data to support a nuanced class/gender analysis. That said, the foregrounding of this paper is necessarily about women and their career trajectory, because of the gendered nature of care and caring work, as discussed above via a care ethics discourse, but class cannot be dismissed as a meaningless factor in experiencing care-less spaces, practically, emotionally and socio-politically. All three women were at different phases of their academic careers. Megan - a post-doctoral researcher, Donna - a senior lecturer and Wendi - a professor, were interviewed for a minimum of two hours. All women were accessed via personal networks (author g), and so as I have already stipulated, they were purposefully sampled, which means broader issues can be discussed, but no generalisations made (Hoskins, 2010).

The style of interview was unstructured, in-depth and life story focused (Plummer 2001, Ribbens and Edwards 1998). All three had experiences of working in traditional universities, as well as post '92 universities ${ }^{1}$, which meant they could reflect upon differences and similarities, although this was never about comparatives regarding prestigious and post ' 92 university life. All three women were asked, before the interview, to reflect upon their career trajectories. Our interviews involved discussion and reflections about their careers within academia, motivation and pleasure, academic influences, collaboration, collusion, power, identity, leadership, work-life balance, and more generally professional relationships. In many ways, similar to work that has been carried out in recent years, as reactions to, and engagements with, the changing nature of university life (e.g. Hoskins 2010, Pereira 2016, Ryan-Flood and Gill 2010, Sifaki 2016). For the purposes of this paper, I mainly draw upon the data that relates to research relationships and identity.

\section{Ethical candour}

There are always ethical implications in research with human participants, and as such, I gained ethical approval from my university in a traditional manner. Pseudonyms have been used and identifying details changed. So omitting university names, areas of research and so on was necessary. I have written elsewhere about doing ethical and reflexive research (Author a, e) and reflect upon the fact, that I adhere not only to the ethical processes of doing research (safety for participant and researcher, consent, trust, anonymity and so forth), but also observe aspects about how knowledge is generated, and how research is presented, ethically. In addition, I recognise my gendered and classed roots will no doubt have impacted upon the interactive

\footnotetext{
${ }^{1}$ Post' 92 universities were old polytechnic colleges in the UK.

Page | 6
} 
interviewing carried out and my reading and interpretation of the data. Not least as it can bring a limitation to this exploration as my own class position raises ethical questions. As Hoskins (2010: 136) has stated, 'I have a working class background which shaped the interview process and relationship through the identification of shared norms and values'. But my position and my participant's stories, although particular, serve as a springboard in speaking out about issues that touch many women academics. Being silenced, or simply ignoring such emotive and illuminating narratives could be considered unethical, care-less and damaging (see also RyanFlood and Gill, 2010). Moreover, within gendered research contexts, and within the academy, women's voices need to be heard and listened to.

\section{Analysing the data}

As a result of my own subjective locus, I took a reflexive and thematic approach to analysing the data (Plummer 2001, Ribbens and Edwards 1998), as all three women spoke candidly about their positions, how they felt as an academic, and what types of relationships they had at work. This resulted in narratives that revealed how senior women colleagues colluded with the institutional practices, (or behaved in coercive and abusive ways) when it came to publication of research material and feedback, feelings of not being good enough, and situations that provoked an overwhelming desire to flee the academy. These themes are discussed in more detail below, but in closing here, I reflect upon the tensions between autobiography, gender and the academy in hearing other women's voices, as Reay (2000: 19) says in her work,

Whenever I have tried to publish anything that attempts to remain faithful to the women's accounts, referees invariably ask for more theorising and less of the women's voices. Working-class women's own analyses of their situation are frequently seen as anecdotal or merely descriptive.

\section{Findings and Discussion}

\section{Complicity and 'faking' it: identity, class and care-less spaces}

Megan, Donna and Wendi's narratives evidence how their academic identities starkly brought to the fore, a 'bogus' sense of self. This meant that before entering into relationships with academic others, complying with institutional machinations, 'faking' intellectual prowess or simply not feeling worthy of existing within academia seemed palpable. Arguably this could be a result of classed and gendered identities (Reay 2004). Largely because the 'cost' and difficulties of 'managing a desire not to be, and not to be seen as being, better than those they have 'left behind' in class terms; a disavowal of being superior, yet underneath a lingering sense of not feeling worthy' (Hoskins 2010, 139) is evident. Wendi, a Professor of Sociology at a prestigious university said, 'I'm complicit and I'm ambivalent and that's crazy, [and] I've always had a problem with academia; the legitimacy of it'. The gendered and classed identity for Wendi has played a role in how she negotiated her relationships during school and beyond, as Wendi continued, 'I had a shit time at school, hated it, hated, hated it, that's how I understood myself, you know, I wasn't, I would never consider myself academic whatsoever'. Yet, clearly Wendi colludes with dominant ideas around academia rather than wholly resisting them, as she says herself, 'I'm complicit and ambivalent'.

Donna, a Senior lecturer in Sociology at a 1960s university, reminisced about this aspect of her education too, and expressed 'my mum was always getting letters home, saying I wasn't at school, but she was a single mum and had to work. Didn't really have any control over what I did, once she left the house in the morning'. Furthermore, Megan, a Research Fellow at a post '92 university, articulated this aspect of classed academic identity clearly, when she said on Page $\mid 7$ 
more than one occasion, during the interview, she was a 'fake' and not worthy, for example, 'I think there's an imposter syndrome, you know that you don't quite believe you're good enough, even now I don't use Dr very often because I'm uncomfortable, because it sounds a little bit pretentious (laughs). I've waited so long to be able to call myself Dr, and now I don't blooming use it'. This attempt at distancing the self from an academic title, or the academic marking, (Goffman, 1990) that occurs as a result of upward social mobility is arguably collision, too as it is all too easy to look back on classed roots from an elevated position. This distancing practice is also evident in Wendi's narrative. Wendi said she did not really like to use her professor title, and went as far as to say she was too uncomfortable, as 'I have felt with slight discomfort the professor thing. It does make a difference, and it's not always fair, and sometimes, in the way others relate to you. It's like they're less relaxed around you'. Conversely, Donna said 'I worked bloody hard for my title, and I love using it, especially when I confound people's expectations of me with my working class accent an'all'. Women academics therefore, particularly working class ones, are continuously playing a balancing game between serving the academy by being complicit, and identifying with their working class identity.

Clearly for these three women, a classed narrative occurs, as we begin to consider their stories about history, biography and identity. Moreover, if working class women academics are starting their working relationships from the assumption that certain academics are better than others and therefore have a 'good way with words, they write beautifully [and] know how to write a very good high end level academic paper', as Megan expressed, then clearly there are going to be some classed identity challenges. Just as emotions such as 'fantasies, desires, fears and defences', (Gillies and Lucey, 2007: 3) for working class women play a part in embarking on a $\mathrm{PhD}$, they continue to influence, enthuse and sometimes contaminate relationships that develop as a result of being an academic. As Sifaki (2016: 117) asks

how could we share and get involved in future sustainable imaginaries without fake optimism and without reproducing the long-standing exclusions', [and], 'in which way could we participate in an attempt to transform our own negative feelings, without marginalizing them or pretending that they do not exist, into new, more inclusive stances, which will be empowering?

Just as faking optimism, complicity, pleasure, desire, and doing intimacy differently occurs in personal relationships (see also Gabb, 2008), my study reveals how these forms of emotional labour and collusion also appear within the academy which is unacceptable and damaging.

In intimacy research for example, individuals might choose to end a relationship based on lack of physical or emotional satisfaction (Gabb, 2008). Still, others live with this lack and/or find pleasure and satisfaction elsewhere. Just as in some personal relationships, toxic and destructive working relationships and environments can leave individuals inhabiting care-less spaces, as Gill (2010) talks of 'toxic shame' and Lynch (2010) of 'carelessness' in the academy $^{2}$. Notably, Wendi and Donna have at times contemplated leaving their academic posts, when so overwhelmed with relationship challenges at work, and it is fair to say that not all working relationships are pleasurable and many do not result in friendship, but surely we at least expect care-full and generous ones? (Back, 2016). After all, we anticipate those in care work professions do care-full work and manage emotional labour well, although evidently this is not always successful (Author b, f, Lynch et al. 2009). Moreover, being caring is still

\footnotetext{
${ }^{2}$ See below, but in addition, care-less-ness is grounded within both my care ethics model and a feminist care ethics. Ultimately, Lynch (2010) and I are able to envisage care-less spaces (author, b) or care-less academic structures (Lynch, 2010) within the academy for women.
}

Page 8 
gendered (Lynch, 2010), while 'generosity shows suspicious signs of intellectual feebleness' (Back 2016: 115) linking being and doing caring with women and intellectual lack.

Critically, therefore, Megan did resign from her permanent post without securing an alternative position, after becoming so beleaguered by her administrative load and difficult working relationships. It is clear from this narrative how troubled emotionally and physically, she felt as described here.

We live in a mean world, and it doesn't always work. Mean people get things [...] It did all effect my health and I had to see gastroenterologist, and it was all stress related. It scared me, I couldn't change gear and could barely walk to the door, just before I left. I didn't want to compromise my health and family. I did compromise my family, I did compromise my health, because I thought everyone did. Everyone around me was like that. I didn't realise I was unhappy until I was in a role where I'm very happy'.

This worrying emotional and physical deterioration for Megan was as a result of working many hours, throughout the week and over the weekend, she had teenage children and a husband who rarely saw her. This was Megan's first academic post after her PhD completion so felt the added pressure of 'making it work', for her career and future promotion.

Significantly, Lynch (2010: 58) has identified that the 'care-free' academic did not occur as a result of neoliberal capitalism, but that carelessness in education is founded upon a Cartesian position 'of scholarly work, namely that it is separate from emotional thought and feeling and that the focus of education is on educating an autonomous, rational person', furthermore relationality is not considered pivotal to her identity (Lynch 2010: 59). Thinking about this idea of being care-free, agentic or autonomous is critical in the context of women in higher education (Hutchings, 2013) but not without complications. Whilst arguably autonomous, they are always relationally interdependent (Author, b). Not least of all, because starting a research project, such as a PhD is not only an investment in time, it is also an investment that is usually an extension of the self, yet in relation with, more often than not, a superior other. Certainly the intense gratification of following a particular research path driven by an embodied intellectual desire is important. For many academics the highs of carrying out research and then gaining affirmation is a very part of their being and incredibly pleasurable and gratifying.

As it is, the increased intensification and bureaucratisation of the academy has arguably produced care-less-ness and a mean spirited instrumental way of doing academia (Back, 2016). Higher education however, is part of a bigger picture, where through the lens of my care ethics model I am able to highlight, via a combination of emotional, practical and socio-political caring spheres, care-less spaces that feed into each other. Certainly via the narratives of Megan, Donna and Wendi where all spheres interconnect, personal and political aspects of academia merge as Megan said there was little room to breathe, and told me 'I wanted to be a researcher, but I wasn't being given the space [...] I mean being sent something at 5 o'clock on a Friday afternoon and being told that's got to be with the VC's office on Monday morning' does not suggest a healthy working life, and yet she went to on to say she needed to do this to progress her career. Here Megan is mindful of what she needs to do to gain 'credits' at work, and yet this environment is care-less.

For Wendi too, she has experienced both emotional and institutional care-less-ness, due to a breakdown in working relationships and care-less bureaucratic imperatives. 
I ended up going to this meeting, along with HR, and I thought we were all going to be culled. People were in tears. [...] Another time it was the REF thing! she (another senior colleague) was supposed to be doing an impact statement, and days before it was due, it became apparent that it just hadn't written and we all thought it was strange as she wasn't talking to any one or asking about their impact, and me and (an other) had to step in, before it was due, in a total panic, we had to cobble that together, because she just hadn't done it. And she got hauled into management and she told them she hadn't done it because she'd had no cooperation from me!!

Clearly from Wendi's narrative care-less aspects of the academy leak into how relationships are played out. Collaborating and working respectfully and generously with colleagues can be satisfying, and I am not disparaging those real research bonds, but the current research excellence framework (REF) with nuanced impact objectives arguably impose relationships that can enforce the development of faux research centres, groups or relations and create environments where intellectual and academic identity is put under strain at best, destroyed at worst.

As evidenced above via Megan, Donna and Wendi, career paths are fractured. These three women have found themselves faking research associations and professional relationships in collusion with these powerful directives. This is often at the expense of their intellectual pleasure peaks - the pleasure and highs gained from pursuing individual and collegial and genuinely collaborative research goals. Although some might argue that women have been colluding for decades if not centuries in order to keep women in the position of 'second sex' (Madhok, et al., 2013: 1), systemic violence is more pervasive than ever in the academy, for example, via systems and oppressive tools such as REF, management strategies, promotional hurdles, goal posts changes and so on. Crucially if we lose sight of gratifying research, we risk losing scholars with a desire to both teach and research in meaningful ways. Genuinely mutual and care-full relationships work and are indeed fulfilling, but fake ones lead to poor unsatisfying shallow unions that ultimately fail to stand the test of time and can lead to fractured and shattered academic identities (Mauthner and Bell, 2007).

There are many care-less spaces within the academy, and the previous research assessment exercise (RAE) (Alldred and Miller, 2007), and the current REF (Gill and Donaghue, 2015) in the UK, are simply examples of where power dynamics breed care-less-ness, complicity and 'fake' identity construction, within the context of research publications, research centres, performance and mentoring. Moreover, despite the claims that the REF is inclusive and broad, especially when it comes to the impact of research, there are fears that the measurement of impact is being managed in very narrow terms, 'focussed primarily on income-generation for business and industry and direct influence on public policy - and this will penalise the humanities and social sciences as well as critical, emancipatory scholarship' (Pereira, 2015). It is at this point, therefore, I would like to delve deeper into collaboration for women academics.

Publishing and collaboration: care-less spaces

Some academics prefer to collaborate, others like to work alone. This is not news. The three women academics I interviewed were no different. Megan and Wendi worked on research projects with colleagues from before they gained their PhDs, and were very happy in teams. Wendi went as far as to say that she thought working with others was a way of always 'supporting each other' and Megan found working with senior colleagues 'incredibly exciting and supportive'. Conversely, Donna was ambivalent about, if not resistant to, working 
collaboratively. She expressed, she would rather not work with others on her research, although had enjoyed writing with colleagues in the past and said,

I mean there have never been any bust ups. Well only in the sense that I said I didn't want lead authorship once. [...] I wanted it to be 50/50. But when it comes to my research that I feel so desperately involved in, I don't want to share that, I don't really need others, it's my research. My research gets me so excited that I cry and can get really moody, if something doesn't come, I mean if I'm struggling.

She went on to say that she really did not want to work in teams, but that 'we keep getting told we have to get money, money money! It's boring, as I want to pursue my ideas. Ideas don't come with money these days'. Donna's emotive narrative, is not terribly dissimilar to Maddox' (2003) historical reading of Rosalind Franklin, the scientist behind the scenes in the mapping of DNA. Franklin, on being asked about collaboration, caused quite a reaction as evidence here,

Collaborate? She exploded. [...] 'How dare you interpret my data for me!' Rosalind had good reason. Her work was her life, the core of her identity. Undervalued at King's, she had just achieved extraordinary results by working in virtual isolation. Now what she saw as a less able colleague of higher rank was proposing to elbow in and spoil the clarity of her investigation (Maddox, 2003: 154).

This quote shows how intensely opposed to collaboration Franklin was, but we also get a feel for how her research embodied herself, her life, and how research can be painful as at one time she was due for dinner at her brother's house and arrived in tears, "weeping" as he recalled, she was "beyond redemption" (Maddox, 2003: 155). It is clear research desire is deeply embedded in academic identity and a sense of self, and Donna's suggestion that she cries and gets moody confirms this too. Caring and respectful research relationships are pivotal to a healthy identity, whether working together, or alongside each other. But what happens when collaboration does occur, yet relationships are care-less, or if 'ownership' of research is questioned?

From the interview data, it is clear that Megan, Donna and Wendi have experienced care-full relationships where one - sometimes senior academic - will nurture a more junior colleague enabling them to flourish. However, this is not always the case in their stories. Although, according to Donna she has not experienced any difficult relationships when it comes to coauthorship and collaborations, the same cannot be said for Wendi and Megan. This is notable in itself, as both Wendi and Megan desire collaborative and collegial research relationships, whereas Donna has said she is ambivalent. It is evident from the interviews with Wendi and Megan, senior women academics have been care-less in their collusion and demonstrated an absence of respect, leading them both to lack trust and work with caution.

This care-less-ness, or lack of generosity, as Les Back (2016) might suggest, whether intentional or not, is obvious when Wendi reflected upon her past experiences as a junior researcher on a project. Reminiscing, she told me, she had done the bulk, if not all of the data collection and writing on a piece of research at the time. After a while her senior colleague, the 'principal' investigator (PI) who had gained the funding for the project, wanted to claim authorship, despite the fact that Wendi had carried out the research, and written the paper. Wendi told me she had a huge 'bust up' with the PI because she felt 'treated like a child'. Yet, she said,

Page | 11 
I did everything, and then she (PI) came in at the end and said 'right, I'll take that thank you very much', and I said, 'oh no you won't', she assumed that she was going to take first authorship, and it was about to be published, and she hadn't been involved at all, [...] I mean if someone has done a first draft then they get first authorship. It's a negotiation, but to assume authorship, and her arguments were dreadful, like 'but I'm better known'. [...] I think what annoyed me most, I have found this, the women who say they're feminist, are often the bloody worst and that annoyed the hell out of me.

It seems this was not a one off, as Wendi had a similar experience with a senior male academic. More perhaps, about power dynamics and coercion in the academy (Mauthner and Edwards 2007, Madhok et al, 2013) than simply gender per se? With the research output Wendi talked about she did stand her ground, and claimed first authorship, but on another occasion she, in discussion with a women colleague, did not fight back, and relented on gaining first authorship despite having written the work and said, 'I learned you have to pick your arguments'. It seemed on this occasion she had 'more to lose' and so this negotiation of relationships becomes an art form in itself and indeed, perhaps a form of collusion? Furthermore, those who are seemingly not able to cooperate, work collegially, or coerce people, suffer as a result.

Like Wendi, Megan too discusses the tricky subject of authorship and collaboration. She was challenged during the publication phase of a project, when her senior colleagues had previously discussed they would all lead on one paper each. However, what occurred was care-less behaviour by senior colleagues as Megan said about the paper she had written,

it was done over many meetings and it was written in stone that this was going to happen, and how it was going to work, and I was going to lead on a particular paper, so I wrote the paper and I gave it to them and at that point they read it and they said 'this is great, we think it needs some topping and tailing, but we think it's there'. And it was yeah, this is brilliant, phew! [...]

Megan went on to say that after the project came to an end they met sporadically as a team. But then,

I suddenly had a bit of silence and I didn't hear anything for a while, and so I contacted them, saying is everything alright, and I didn't hear back, I started to panic, what's going on here, and then I eventually got an email saying sorry we've not been in touch, blah blah, blah, and we had a meeting and it was very awkward and they were trying to be very polite and they were saying, 'we want you to rework the paper', and that's fine, and I don't have any problem with anyone saying, this could be better or this needs strengthening, as it's part of the process, part of constructive criticism. Erm, but they didn't like it, I was like, 'you tell me how you feel you want it', and I was given a very exact brief of how many words, for each section, I'd never worked like that but you're the PIs if that's how you want it, so I reworked the paper again, I mean it's a better paper for it, no doubt, but it took a lot of reworking, [...] so I went away and did it again, and then I got an email, after quite a long silence saying actually we've decided we're not going to submit your paper, we've re-written it, and we're just going to put you on as third author on our paper (pause) it just completely floored me. 
This narrative highlights the lack of care from the senior colleagues, even if unintentional. Megan was in her first research post, having only just finished her $\mathrm{PhD}$, and therefore it could be argued, would need a little more nurturing and care-full support. Significantly both Megan and Wendi have held contract research posts, and worked in teams for big research projects, but Donna has only ever held lecturing posts. It is care-less to make assumptions that academics want to collaborate or to assume that they want to work alone. What is clear is that working with others has different meanings for different people, yet, all this aside, working together or alone, being supportive is crucial. Furthermore, as harsh as this might seem, Reay's (2004: 37), discussion of Bourdieu's symbolic violence resonates here as 'academics are not just producers of symbolic violence in their depictions of the social world; they maintain and perpetuate symbolic violence in their interactions with each other, and specifically in the traditional research team'. This is deeply worrying.

Yet as Young (2000: 74) suggests people are often ignorant about other people's lives and, 'perhaps more often people come to a situation of political discussion with a stock of empty generalisations, false assumptions, or incomplete and biased pictures of the needs, aspirations and histories of others'. People, and in this case academics, might hold assumptions about other people and they are often dependent on a limited focus and awash with their own agendas. Understanding caring relations in these examples above is not straightforward. Although it might seem Donna is selfish when saying she does not want to share her research time, and the senior academics working with Megan and Wendi who want to claim authorship are care-less, the critique here is not about judging or blaming individuals, but is an attempt to understand care-less-ness within an institutional context, such as the university. My argument is that, if 'we do not speak publicly about, and critically examine, the problematic conditions of life and work within our own academic walls, then our credibility as critics and analysts of what is going on in the world outside them is bound to be similarly diminished' (Butterwick and Dawson, 2005:64). Exploitation, abuse, coercion and complicity are at play within universities and 'top-level positions within higher education are [can be] substantively if not formally defined as care-less positions [...] This carelessness has been endorsed as morally worthy' (Lynch, 2015: 63). I would argue this is dangerous, dehumanising and epitomises care-less spaces.

\section{A way forward: addressing care, collusion and the academy}

Herring (2013: 25), engages with an ethics of care, rather than a rights based approach when critically appraising legal systems. He suggests that we are all 'ignorant, vulnerable, interdependent individuals, whose strength and reality is not our autonomy, but our relationships with others' (ibid: 46). So therefore he does not premise a legal and ethical toolbox on the basis of individual rights, but instead on ethical and interdependent caring relations. This means that whilst caring work is not necessarily about love, 'emotions are central to good care' (ibid: 57). This is revealing here for two reasons: Herring (2013) is talking about so called 'objective' legal systems and I am talking about the academy where 'objective' knowledge is privileged. It is also interesting here, when considering women's stories about their academic careers, identity construction and complicity within the work place in considering care-less spaces, as Herring argues 'respect and acceptance of responsibility' are central in understanding caring and the law (ibid). Moreover, 'relationships are made up of more than the doing of deeds and the saying of words. A touch, an expression, the slightest smile, can convey great warmth' (Herring, 2013: 24-25). Yet more often than not the law and criminal justice system (CJS) is care-less. Moreover, and critical in reflecting upon the 
academy and working relationships, arguably the CJS does not necessarily 'require love or even affection' (ibid). Megan, Donna and Wendi were never under the illusion that all their working relationships would be personal or affectionate. Love and affection is not necessary for career development and a healthy academic identity, but I would argue that caring and carefull relationships are.

By interpreting what Megan, Donna and Wendi have to say, it is evident they have experienced care-less spaces within the emotional, practical and socio-political caring spheres. But the whole space might not be care-less. Some relationships are care-full and they found strategies to sustain themselves through relationships with others. Yet their narratives do suggest they have come into contact with people in the academy who deny wrong doing, lack responsibility, (Tronto 2011) flee from obligation, (Korsgaard, 2009) and ultimately lack generosity and respect. As it is, the academy struggles with anything that is not about autonomous individuals and bureaucratic systems - it recoils from emotions, just like the CJS and law. As Herring (2013) suggests, we need to re-evaluate how values that underpin the law are conceptualised, and I would argue we too need to consider this within the academy. So for example, rather than focussing simply on the individual and rights based models, where often one person or organisation is pitched against another, we ought to recognise the significance of relational values. Care-full-ness is a relational, interdependent practice between two or more people. Higher education and other socio-political systems, such as the REF, do not deal with emotions and caring terribly well.

My argument has been that care-less spaces are pervasive, and within higher education exist through daily care-less practices. I propose caring and care-full practices in nurturing research relationships. Moreover, it is often via desire and motivation to do research that flourishing occurs. However, bureaucratic systems hinder creativity and systemic tools to measure worth encourage competition, complicity and care-less-ness. In turn care-less spaces develop where women academics are coerced into faux relationships, are restricted emotionally and practically, and then compete with each other (Skelton, 2005). More often than not colluding with the academy for benefits that nurture an embodied yet fractured research self. Significantly Hutchings (2013) identifies that there will always be pain in the context of feminist ethical and political agency because we live in a plural and unequal world ${ }^{3}$, yet, optimistically I suggest care-full interdependent relations in the academy are the way forward, and respect, responsibility and trust are key to their development. This will only occur if all caring spheres work together, so socio-political systems deliver care-full practices and policies, that trust academics to do their work, and powerful others nurture junior colleagues emotionally and practically in a care-full manner.

\section{References}

Ahmed, S. (2010) 'Secrets and silence in feminist research' in R. Ryan-Flood and R. Gill (eds) Secrecy and Silence in the Research Process: Feminist Reflections Oxon, Routledge.

\footnotetext{
${ }^{3}$ There is a political theory debate to have here about choosers and losers within a feminist and ethical framework, for example, the 'choice' between feminism where 'agentic choice is known by its outcomes and is authoritative for everyone, or one in which agentic choice is a process and agency may validate any number of substantive outcomes' (Hutchings, 2013: 19), but I do not have the capacity here to follow up the argument in this paper.

Page | 14
} 
Aiston, S. J. (2014) 'Leading the academy or being led? Hong Kong women academics' Higher Education Research and Development, 33 (1) 50-72.

Alldred, P. and Miller, T. (2007) 'Measuring what's valued or valuing what's measured? Knowledge production and the research assessment exercise' in V, Gillies and H, Lucey (eds.) Power, Knowledge and the Academy: The Institutional Is Political Houndmills, Palgrave Macmillan. Pp. 147-167.

Back, L. (2016) Academic Diary: Or Why Higher Education Still Matters London, Goldsmiths Press.

Butterwick, S. and Dawson, J. (2005) 'Undone business: Examining the production of academic labour' Women's Studies International Forum 28, 51 - 65

Evans, M. (2004) Killing Thinking: The Death of the Universities London: Continuum

Evans, M (2011) 'Doing gender: Gender and women's studies in the twenty first century' Women's Studies International Forum 34 603-610

Gabb, J. (2008) Researching Intimacy in Families Houndmills, Palgrave Macmillan

Gill, R (2010) 'Breaking the silence: the hidden injuries of the neoliberal university' in R, Ryan-Flood and R, Gill, (2010) (eds.) Secrecy and Silence in the research process: feminist reflections Oxon, Routledge. Pp. 228-244.

Gill, R. and Donaghue, N. (2016) 'Resilience, apps and reluctant individualism: Technologies of self in neoliberal academy', Women's Studies International Forum, 54 91-99

Gillies, V. and Lucey, H. (2007) (eds.) Power, Knowledge and the Academy: The Institutional Is Political Houndmills, Palgrave Macmillan

Goffman, E. (1990). Stigma: Notes on the Management of Spoiled Identity. London: Penguin Books.

Herring, J. (2013) Caring and the Law Oxford, Hart Publishing Ltd.

Hoskins, K. (2010) 'The price of success? The experiences of three senior working class female academics in the UK' Women's Studies International Forum 33 134-140

Hutchings, K. (2013) 'Choosers or Losers? Feminist Ethical and Political Agency in a Plural and Unequal World' in S. Madhok, A. Phillips, and K. Wilson (eds.) Gender, Agency and Coercion, Houndmills, Palgrave Macmillan. Pp. 14-28.

Korsgaard, C. (2009) Self-constitution: Agency, Identity and Integrity Oxford, Oxford University Press.

Lewis, G. (2010) 'Animating hatreds: research encounters, organisation secrets, emotional truths' in R, Ryan-Flood and R, Gill, (2010) (eds.) Secrecy and Silence in the research process: feminist reflections Oxon, Routledge. Pp. 211-227. 
Lynch, K. (2010) 'Carelessness: A hidden doxa of higher education' Arts and Humanities in Higher Education 9 (1): 54-67.

Lynch, K., Baker, J. and Lyons, M. (eds) (2009) Affective Equality: Love, Care and Injustice Houndmills, Palgrave Macmillan.

Maddox, B. (2003) Rosalind Franklin: The Dark Lady of DNA, New York, Perennial Press

Madhok, S., Phillips, A., and Wilson, K., (eds.) Gender, Agency and Coercion, Houndmills, Palgrave Macmillan.

Mahon, R. and Robinson F. (eds.) (2011) Feminist Ethics and Social Policy: Towards a New Global Political Economy of Care Canada, University of British Columbia Press.

Mauthner, M. and Bell, L. (2007) Power Relationships in Research Teams' in, V, Gillies and H, Lucey (eds.) Power, Knowledge and the Academy: The Institutional Is Political Houndmills, Palgrave Macmillan. Pp. 88-104.

Mauthner, M., Birch, M., Jessop, J. and Miller, T. (2002) Ethics in Qualitative Research, London: Sage.

Mauthner, M. and Edwards, R. (2007) 'Feminism, the Relational Micro-Politics of Power and Research Management in Higher Education' in V, Gillies and H, Lucey (eds.) Power, Knowledge and the Academy: The Institutional Is Political Houndmills, Palgrave Macmillan. Pp. 168-188.

Morley, L. (2014), 'Lost leaders: women in the global academy' Higher Education Research and Development 33 (1) 114-128.

Noddings, N. (2003 [1984]) Caring: A Feminine Appproach to Ethics and Moral Education London, University of California Press.

Nussbaum, M. C. (2011) Creating Capabilities: The Human Development Approach USA, Harvard University Press.

Pereira, M. (2016) 'Struggling within and beyond the Performative University: Articulating activism and work in an "academia without walls" Women's Studies International Forum 54 $100-110$

Philip, G., Rogers, C. and Weller, S. (2013) 'Understanding Care, Thinking with Care' in C, Rogers and S, Weller [eds.] Critical Approaches to Care: Understanding caring relations, identities and cultures London, Routledge. Pp. 1-17.

Plummer, K. (2001) Documents of Life 2: An Invitation to a Critical Humanism London, Sage.

Reay, D. (2000) "'Dim dross": Marginalised women both inside and outside the academy' Women's Studies International Forum 23 (1) 13-21, 
Reay, D. (2002) 'Shaun's Story: troubling discourses of white working-class masculinities', Gender and Education, 14:3, 221 - 234

Reay, D. (2004) 'Cultural capitalists and academic habitus: Classed and gendered labour in UK higher education' Women's Studies International Forum 27, 31-39

Ribbens, J. and Edwards, R. (1998) Feminist Dilemmas in Qualitative Research London, Sage.

Robinson, F. (2011) The Ethics of Care: A Feminist Approach to Human Security Philadelphia, Temple University Press.

Ruddick, S. (1989) Maternal Thinking: Toward a Politics of Peace, Boston, Mass: Beacon Press.

Ryan-Flood, R., and Gill, R. (2010) (eds.) Secrecy and Silence in the research process: feminist reflections Oxon, Routledge.

Sifaki, A. (2016) 'Which side are we on? Feminist studies in the time of neoliberalism or neoliberal feminist studies?' Women's Studies International Forum 54, 111-118.

Skelton, C. (2005) 'The 'individualized' (woman) in the academy: Ulrich Beck, gender and power' Gender and Education, 17:3, 319-332

Tronto, J. (1993) Moral Boundaries: A Political Argument for an Ethic of Care London, Routledge.

Tronto, J. (2011) 'A feminist democratic ethics of care and global care workers' in R. Mahon and F. Robinson (eds.) Feminist Ethics and Social Policy: Towards a New Global Political Economy of Care Canada, University of British Columbia Press. Pp. 162-177.

Young, I. M. (2000) Inclusion and Democracy New York, Oxford University Press. 